\title{
The integration of character education in local tradition: an ethnographic study
}

\author{
I Made Ariasa Giri ${ }^{1}$, and I Ketut Ngurah Ardiawan ${ }^{2}$ \\ ${ }^{1}$ STAHN Mpu Kuturan Singaraja, Primary Teacher Education Department, 81112, Bali, Indonesia \\ ${ }^{2}$ STAHN Mpu Kuturan Singaraja, Primary Teacher Education Department, 81112, Bali, Indonesia
}

\begin{abstract}
The significance of character education has becoming an appealing issue to be discussed. Its significance has been brought to school through a number of practices. In fact, character education is not merely the result of schooling but this is a widespread from integration of character education in local culture. This present study attempts to explore character values contained within a local genius called subak pancoran. Further, this study is a qualitative study by utilizing ethnographic design. It was conducted in Buleleng regency, Bali. There are three ways that the researcher uses to collect the data, namely interview, observation sheet, and field notes. The subjects are selected purposefully. Accordingly, the collected data are analysed qualitatively. This study reveals that subak pancoran tradition emphasis on the following characters; tolerance, religious, democratic, communicative, hard work, responsible, mutual help, and environmental awareness. The children character development cannot be separated from the culture where children live and grow. The contribution of this study to the board of knowledge will also be added.
\end{abstract}

Keywords: Integration, Character Education, Local Genius

\section{Introduction}

Character education has emerged as an appealing issue for years. This term was initially proposed by Lickona [11] that sees the importance of character education. He later sees character education is not merely teaching what is right and what is wrong to children, but more than that character education inculcate habituation of the good that students understand, able to feel, and want to do good. In addition, Dantes [8] closely looks at the components of good characters as the following; moral knowing, moral feeling, and moral action.

The emergence of character education to the field as it is now is also much influenced by the fact that family nowadays often provide less supervision to their children $[5,4]$.

\footnotetext{
${ }^{1}$ tiyagiri@yahoo.com

${ }^{2}$ stahnmpukuturansingaraja@gmail.com
} 
Because of technology and the advancement of education, families are leaving the core of development of their children up to the schools. Hence, there must be a way to insert character education in any way possible. One of the ways is that by integrating it in local culture.

In Indonesian context, preservation on local cultures in Indonesia has been degrading and there is a tendency that people neglect culture as a local genius, which in fact, is the main characteristic that holds Indonesian diversity. This has concerned the Indonesian government which results in developing Indonesian present curriculum (Curriculum 2013). It emphasizes on education process should be originated from present and future national culture [9]. The government seems to be quite aware of the importance of culture which functions as living well each other [6].

Specifically in Bali, Balinese society has seen local genius as an inseparable part to ways of life. A difference in religion is no longer a matter and obstacle to insert moral code and local genius as well as culture as a part of building a good character in daily application. Rasna [3] find out that character education in Bali emphasizes on individual ethic dimension and checking on how right and wrong are developed. One of the wellknown local geniuses in Bali is subak pancoran.

Subak pancoran is a pluralistic area where it contains uniting factor to create a social integration within it. The members of subak pancoran consist of Hindus members and Muslim members. It is located in the northern part of Bali, precisely in Panji Anom village, Sukasada district, Buleleng regency. A general description of Panji Anom village is presented as follows. This village is one of the villages which are located in Sukasada district, Buleleng regency. In order to reach this village, a visitor should take a route from the town to this village for $12 \mathrm{~km}$ long. This village is divided into four sub areas, namely Dusun Batu Pulu, Dusun Leabah Siung, Dusun Pancoran, and Dusun Abasan. From these four areas, Subak Pancoran is located at the areas of Dusun Pancoran. The villagers in this area are heterogeneous in terms of the religion and the occupation. Most of them work as farmer. Subak Pancoran has four adjacent, they are Subak Cempaka on the southern part, Pangkung Seka Lalang on the eastern part, Subak Lebah Siung on the northern part, and Tukad Sari on the western part.

In this present study focuses on identifying the character values contained in the subak pancoran tradition from ethno pedagogy perspective, investigating how the character values are integrated in primary school instructions. Further, the findings of this study are expected to enrich the knowledge regarding the character values and local genius as well as giving valuable suggestions to practitioners on how to design localization based instructions.

A number of studies have been conducted in relation to ethnopedagogy and local genius. Orshaak and Orshaak [2] focus their study on analysing Tuvanese ethnic culture in education as well as its compliance toward board knowledge. They found out that ethnopedagogy allows students to identify the degree of importance of aspects of their own culture and value orientations with the help of techniques. Focusing on Indonesian context, [1] analyse the function of Kalosara as ethnopedagogic media in nation character-building in South Sulawesi. They revealed that inserting ethnic or local culture in education let students to be more appreciative of their own culture and strengthen the relationship among people.

Similar studies are also conducted to the population in Siberian $[7,12,13]$. All of those experts focus on revealing the national peculiarities of physical cultures, original physical education, functions and meaning of traditional games and sports. The authors listed above express a great concern about the lack of attention to the problem of studying, preservation and implementation of traditional forms of motion activities of indigenous populations of west Siberian into education process. 


\section{Method}

The researcher identifies the character values contained within Subak Pancoran tradition from ethno pedagogy perspective as well as investigating the integration of character values in Subak Pancoran tradition into learning in schools by using ethnographic in qualitative approach. The scope of this present study is limited to Pancoran by analyzing the character values from the general description and activities exist in Subak Pancoran tradition. Regarding the activities, the researcher searches for information from public figures, community leaders, local residents who are relevant to the field of study.

This research was conducted in Buleleng Regency. The setting of this research was in Pancoran Village, Panji Anom Village, Sukasada District, Buleleng Regency. This research was conducted on October to December 2016. This study covered preparation phase including: 1) stating problems, 2) review of data sources, and 3) instrument and proposal construction. The second phase is the implementation of the study including: 1) data collection, 2) tabulation and data analysis, and 3) data interpretation. Thereunto, the third phase is report construction of the research findings. The data were collected through several techniques such as interview, observation, and field notes. In order to analyze the data of the study, the researcher needed a valid instrument. Thus, the researcher constructed an interview guide and observation sheet as well as the field notes form. The collected data were further analyzed inductively as adapted by Miles and Huberman. The analysis comprises four stages, namely data collection, data reduction, data presentation, and conclusion remarks.

\section{Findings And Discussion}

From the result of observation as well as interview to the leading figure in the community, the researcher found out that Subak Pancoran was formed in 1820 in the same location as it is now in Panji Anom Village, Sukasada District, Buleleng Regency which is $15 \mathrm{Km}$ from the sub-district city, about $12 \mathrm{Km}$ from the capital city, and about $90 \mathrm{~km}$ from the center of the province. There are four boundaries of this area, starting from the (1) southern part which is Subak Cempaka, (2) Pangkung Seka Lalang in the eastern part, (3)Subak Lebah Siung in the northern part, (4) Tukad Sari in the western part.

The land in Subak Pancoran is in the form of gray regusal soil, with frequent terraced rice field, with a height of $250 \mathrm{~m}$ to $450 \mathrm{~m}$. In addition, the large of subak area is $61.00 \mathrm{Ha}$, divided into two smaller areas, namely: Tekad Sari tempekan and tempekan Seka Lalang.

Each religion encompasses a comprehensive essence of peaceful life, including a tolerant life in a plural society. Religion contains the noble order and rule, each of which avoids disputes and prefer the road of peace. This is because every religion has fundamental values underlying it. The Balinese people believe that the fundamental and universal values are contained in the Tri Hita Karana which covers three causes of harmony in life that underlies every traditional organization in Bali such as pakraman village, traditional banjar, sekehe including Subak. The same thing was expressed by Sudarta (2004) who says that the philosophy of Tri Hita Karana is not only applied in subak, but has popularized, entrenched and animated almost all the living and livelihood of Hindu people in Bali.

A harmonious life requires a person full good of character. From an anthropological point of view, character education is a noble character that everyone nurtures. This statement contains a message that human way of life cannot be separated from its basic character. In the context of education, if teachers can control the character, such as anger, the education process is expected to run better. Conversely, if the basic character of anger is put forward, it is possible that there will be disagreement as a social phenomenon [3]. The 
visualization of character values in the real life based on the philosophy of Tri Hita Karana can be seen as follows.

Table 1. The Elaboration of Character Values from Subak Pancoran Tradition

\begin{tabular}{|c|c|c|}
\hline \multicolumn{3}{|c|}{ A Harmonious Relationship between Human and the Almighty God (Parahyangan) } \\
\hline Aspect & Implementation & Character Values \\
\hline \multirow{4}{*}{$\begin{array}{l}\text { Temple and } \\
\text { Mosque as the } \\
\text { symbol of Subak } \\
\text { Pancoran }\end{array}$} & The Mosque and temple are built side by side & \multirow{6}{*}{$\begin{array}{ll}\checkmark & \text { Religious } \\
\checkmark & \text { Tolerance } \\
\checkmark & \text { Environmental } \\
& \text { awareness } \\
\checkmark & \text { Hard work } \\
\checkmark & \text { Responsibility }\end{array}$} \\
\hline & $\begin{array}{l}\text { The Subak temple consists of Ulun Suwi } \\
\text { Temple and Bedugul temple }\end{array}$ & \\
\hline & $\begin{array}{l}\text { Subak temple was built in } 1960 \text { and finalized } \\
\text { in } 1970\end{array}$ & \\
\hline & The mosque was built in 1992 & \\
\hline Worship & $\begin{array}{l}\text { Every Hindu's and Muslim farmer prays in } \\
\text { his/her house of worship, even it was built } \\
\text { side by side and hold the prayer at the same } \\
\text { time, the worship is done solemnly }\end{array}$ & \\
\hline $\begin{array}{l}\text { Pest restriction, } \\
\text { rice plantation, } \\
\text { harvesting }\end{array}$ & Each religion holds its own ways of ceremony & \\
\hline
\end{tabular}

Table 2. The Elaboration of Character Values from Subak Pancoran Tradition (Pawongan)

\begin{tabular}{|c|c|c|}
\hline \multicolumn{3}{|c|}{ A Harmonious Relation between Human and Human (Pawongan) } \\
\hline Aspect & Implementation & Character Values \\
\hline $\begin{array}{l}\text { Informal } \\
\text { leadership }\end{array}$ & $\begin{array}{l}\text { There was once Mr. Husaini who was a } \\
\text { Muslim elected as the chief of Subak } \\
\text { Pancoran }\end{array}$ & \multirow{5}{*}{$\begin{array}{ll}\checkmark & \text { Responsible } \\
\checkmark & \text { Discipline } \\
\checkmark & \text { Fair } \\
\checkmark & \text { Friendly } \\
\checkmark & \text { Honest } \\
\checkmark & \text { Democratic }\end{array}$} \\
\hline Membership & $\begin{array}{l}\text { The membership of Subak Pancoran is } \\
\text { divided into to }\end{array}$ & \\
\hline $\begin{array}{l}\text { Rules in Subak } \\
\text { Pancoran }\end{array}$ & $\begin{array}{l}\text { Balinese language is obligatory in daily } \\
\text { communication }\end{array}$ & \\
\hline Mutual watering & $\begin{array}{l}\text { This activity is about lending water flows to } \\
\text { other farmers in turn }\end{array}$ & \\
\hline Money lending & $\begin{array}{l}\text { This activity is about saving and lending } \\
\text { money amongst farmers }\end{array}$ & \\
\hline
\end{tabular}


Table 3. The Elaboration of Character Values from Subak Pancoran Tradition (Palemahan)

\begin{tabular}{|c|c|c|}
\hline \multicolumn{3}{|c|}{ A Harmonious Relationship between Human and Environment } \\
\hline Aspects & Implementation & Character Values \\
\hline $\begin{array}{l}\text { Pest restriction, } \\
\text { rice plantation, } \\
\text { harvesting }\end{array}$ & $\begin{array}{l}\text { Member of subak both from Hindu's and } \\
\text { Muslim help each other to catch pests using } \\
\text { crab carcass }\end{array}$ & $\begin{array}{ll}\checkmark & \text { Mutual Help } \\
\checkmark & \text { Responsible } \\
\checkmark & \text { Fair }\end{array}$ \\
\hline Water distribution & $\begin{array}{l}\text { Water distribution is administered through } \\
\text { three systems, they are Ngulu, Maongin, and } \\
\text { Ngasep }\end{array}$ & $\checkmark$ Hard Work \\
\hline
\end{tabular}

In relation to the aforementioned matter, Subak Pancoran tradition is actively contributing to enrich the life of the nation. This is reflected by the implementation of local genius which are religious, tolerance, environmental awareness, hard work, responsible, discipline, fair, friendly, honest, democratic, mutual help within Subak Pancoran. In this respect, people discover many benefits within culture to spread awareness on how important character values are. Subak Pancoran tradition also contributes to philosophical values, anthropology, sociology, psychology as the source of study of ethno pedagogy. In addition, ethno pedagogy contributes to character education is a basis and pillar toward better education in 21 st century. Moral values are lived in a form of good action, whether in the process of education or social living. Basically, those activities are the manifestation of character values contained in Tri Hita Karana. It is also clear that its implementation has gone deep within society ways of life and has become a tradition preserved by the people.

Taking into account to the integration of character values, a harmonious live should occur in both Hindu's and Muslim's adherents. Socio-cultural living in Subak can be viewed from historical, structure, and the functional, and participation of Subak members. This can be seen from the relationship pattern or interaction that occurs among Subak members. In relation to the interaction, character values are implemented in form of fundamental activities which aims at uniting all members.

Primary school is an institution which aims to deliver basic needs toward learners such as knowledge, skills, proper attitude education, and prepare them to continue to the next step of their education (Suharjo:1). Schools do not only function as establish learners to have cognitive aspect, but also form students' attitude. Therefore, character values or character education is one that can be developed in school. It can be inserted through instructional process. Teacher may utilize local genius to be inserted thematically within any subject. By integrating it, students are expected to understand their own local genius, which by far will affect them to love their own culture. Nonetheless, teacher should adjust the character values insertion to children development, materials, strategy, method as well as the teaching media. For instance, teacher may come up with a theme, "the place where I live". This theme can be integrated to all subjects, i.e. 1) mathematics; students are asked to count the members participated in Subak, 2) Natural Science; students are asked to participate in rice plantation, harvesting, watering, etc., 3) social science; students are asked to explain the activities conducted by farmers in Subak Pancoran, 4) civil education: students are asked to explain how to live in harmoniously and with tolerance, and 5)Indonesian language; students are asked to catch the meaning of the vernacular language used by farmers and explain it in Indonesia. Those examples are some ways to integrate character values of Subak Pancoran into instructional process in primary schools. By this integration, students' are expected to understand and be able to build the character of local genius to be their own. 


\section{Conclusion}

Subak Pancoran which is located in Panji Anom village, Sukasada district, Buleleng regency plays a role in educating the society. This is shown by deep application of local genius through religion, tolerance, environmental awareness, hard work, responsibility, discipline, fair, friendly, honesty, democratic, and mutual help. Subak Pancoran tradition positively contributes to philosophical, anthropological, socialogical, psychological aspects of ethno pedagogy. This further emphasizes that character education are the basis and pillar toward education in 21 st era.

In relation to the aforementioned explanation, Subak Pancoran plays a key role in integrating local genius in instructional process in primary schools by adjusting it to children development, strategy, method, and teaching media used. This integration process can be done for all subject matter in schools.

\section{Acknowledgement}

The success and final outcome of this research requires a lot of guidance and assistance from many people and the researcher fortunate to have got this all along the completion of the research within the time given. I respect and thank the committees for giving the researcher to revise and complete the research based on the revision given.

\section{References}

1. A.Hafid, Amiruddin, K.Suardika,Sartono,Peribadi, Inter. Res. Jour. of Emer. Tre. in Multi. 1, 9 (2015)

2. H.D.N.Oorshak, S.Y. Oorshak, Jour. of Sib. Fed. Uni, 3, 7 (2014)

3. I.W.Rasna, Jurn. Kaj. Bali. 6,1(2016).

4. K, Larson. Understanding the Importance of Character Education. (Stout, 2009)

5. M, Benigni. Amer. Sch. Boa. Journ. 193, 3 (2006)

6. M,A, Reinfeld. Journ. of Pub. and Inter. Aff. 14 (2003)

7. N. Sinavskiy, Ethno-pedagogic of physical training of the peoples of the North (Khanty and Mansy) (Moscow, 2005)

8. N.Dantes, Techno-humanistic-based Character Education (A. Series of Perspektives and Education Policies for Meeting Global Challenges, (2012)

9. S. Ndiung, The 1st International Conference on Language, Literature and Teaching (2017)

10. Supraptiningrum, Agustini. Jurn. Pend. Kar. 2, 2015

11. T, Lickona, Educating for Character: How Our School Can Teach Respect and Responsibility. (Sydney, 1991)

12. V. Krasilnikov, Folklore and national traditions in physical education of Siberian children (Chelyabinsk, Institute culture, 1998)

13. V. Krasilnikov, Games and competitions in traditional physical training of Khanti. (Yekateringurg, 2002).

14. W.Sudarta, Beragam Nilai Tradisional Subak (Konsepsi yang Relevan dengan Inovasi) Dalam Revitalisasi Subak Dalam Memasuki Era Globalisasi (Yogyakarta, 2004). 